\title{
22
}

\section{HUMANITARIAN SMUGGLING IN A TIME OF RESTRICTING AND CRIMINALIZING MOBILITY}

\author{
Ilse van Liempt
}

\begin{abstract}
Introduction
If we are to win the fight against the smugglers, Europe needs to be ready to take action in order to seize the boats, destroy them and arrest the smugglers and bring them to justice.

European Commissioner for Migration, Home Affairs and Citizenship, Dimitris

Avramopoulos, 23 April 2015
\end{abstract}

On 23 April 2015, the European Commissioner for Migration, Home Affairs and Citizenship, Dimitris Avramopoulos, and the EU Council expressed their determination to come to grips with people smuggling in the Mediterranean. It is nothing new to blame smugglers for the increase of unexpected arrivals of migrants, but in the current refugee 'crisis,' the issue of migrant smuggling has become very much the center of attention. Fighting against smuggling is most often proposed as the 'solution' to the refugee 'crisis' by politicians in the public arena.

In principle, there are two main reasons why states may be willing to counter human smuggling. The first reason has to do with the fact that smuggling is linked to irregular immigration: although it should be clear that not all smuggled migrants are irregular in the proper sense (many of them being refugees and asylum seekers), smuggling is nonetheless one of the most eye-catching ways (at least for the mass media) by which irregular immigration takes place; fighting it can thus be a way of fighting irregular immigration itself. This line of reasoning fits in the criminological framing that is linked to an increasing demand for migration in poorer parts of the world (van Liempt \& Sersli 2012). Smugglers are in this frame referred to as the 'dark side' or the 'underbelly' of globalization (Moises 2005) who facilitate irregular migration. Smuggled migrants are given an unclear role under this approach: while, on the one hand, they are not necessarily to be criminalized for the mere fact of having been smuggled, on the other hand, it is clear that their rights and needs are not what states are fighting for when they adopt this perspective.

The second reason states may be concerned with human smuggling stems, instead, from the need to protect the migrants themselves from the many risks they may face if smuggled: 
economic exploitation; deception; degrading treatment along the way; and even death. Under this approach, smuggled migrants are perceived as victims of the smugglers who thrive on their aspiration to go abroad. An important assumption behind this logic is that stopping smugglers will result in such pain and misery for irregular migrants that news will get back to potential migrants and they will stop coming. Smugglers are seen as having created migration possibilities for those immigrants that states have defined as unwanted. This is also the logic behind the British government's refusal to support large-scale rescue of irregular migrants in the Mediterranean (Collyer 2016).

The paradox between this 'control and care' reasoning is illustrated very well if we look at how the UN approach to human smuggling differs from the EU approach. Even though it does not formally qualify smuggled migrants as victims, the protection of their rights is among the UN Protocol's main concerns, as is explicitly stated, for example, in Art. 2: "The purpose of this Protocol is to prevent and combat the smuggling of migrants, as well as to promote cooperation among states Parties to that end, while protecting the rights of smuggled migrants." The EU Facilitation Directive, however, describes the role of the smuggled migrant by using verbs ("assisting someone to enter," "to transit," "to stay"), thus revealing that the person is seen as someone actively contributing to the whole deed. The UN Protocol, on the contrary, uses - at least in Art. 3(a) - a noun ("procuring the entry of someone"), thus describing the migrant's position more as the result of another person's action than as an action itself.

Regardless of these differences in how smuggled migrants are seen, in both the UN Protocol and the Facilitation Directive the smuggler's conduct is recognized to have a wrongness of its own: a wrongness that is not a mere reflection of irregular migration, but derives directly from its being a commodification of human beings, an exploitation of the migrant's vulnerability as a source of enrichment, of money-making.

In the sideline of both the Protocol as well as the Directive it is mentioned that it excludes from the scope of the criminalisation "the activities of those who provided support to migrants for humanitarian reasons or on the basis of close family ties." In this chapter, we will focus on this broader perspective on human smuggling. Even though the assumption inherent in many of the policy initiatives around fighting human smuggling and studies around human smuggling is that organized crime is involved (van Liempt \& Sersli 2012, Baird \& van Liempt 2015), it is equally important to bear in mind that smuggling is not perceived as a crime everywhere, always, and by everybody. Academic literature on human smuggling points to evidence that it likely has existed as long as borders have, as there have always been people who, for all sorts of reasons, were unable to travel via ordinary legal routes (Fittko 2000, Siener 2008, Mar 2010).

This chapter puts a broader perspective on human smuggling to illustrate the various reasons migrants might need smugglers and the different ways smuggling can evolve. The category of the 'humanitarian smuggler' is put central in this chapter to challenge the purely criminological discourse around human smuggling that is dominant, and to provide a more complex, diverse picture of the practice.

\section{What do we know about the facilitators behind human smuggling?}

The earliest academic conceptualization of human smuggling comes from Salt and Stein (1997), who framed human smuggling as a 'business.' As geographers, they made important distinctions among the various types of services offered in countries of origin, in transit, and at the destination, as well as the interconnections among these places. They also differentiated between legitimate and illegitimate markets in which actors pursue profit and commercial gain around human smuggling, which has been important in understanding its embeddedness. Despite these 
nuances, human smuggling was tied directly and solely into questions of organized crime, which has been central to discussions of migrant smuggling from early studies until now (Salt and Stein 1997, Chin 1999, Lazcko and Thompson 2000, Salt 2000). Defining the exact role of organised crime in human smuggling organizations generated a lasting debate in smuggling studies (Heckmann 2004, Neske 2006, Colucello and Massey 2007, Kaizen and Nonneman 2007, Kyle and Koslowski 2011, Soudijn and Kleemans 2009, UNODC 2011).

It is not surprising that when the UN Protocol against the Smuggling of Migrants by Land, Air and Sea came into being in 2000, migrant smuggling was officially included in the definition of organized crime. This event marked the framing of human smuggling as a global criminal business (Gallagher and David 2014). In 2000, the strengthening of the penal framework of smuggling was also put high on the European Council's agenda. Its delegations, however, had very different views on the various types of smuggling that exist and what constitutes 'humanitarian' grounds for the smuggling of asylum seekers.

The discussion on a continuum of types of smuggling links to a whole field of academic research that shows that the criminal discourse is helpful for understanding different actors involved in the process of human smuggling and the stages of the process, but it lacks a wider perspective. By following a narrow track dictated by a purely economic perspective, the complexity behind human smuggling is denied. It, for example, does not give any indication of the reasons smuggling begins or continues in a certain context other than making profit (Kyle 2011, van Liempt 2007, Spener 2009; Kyle and Dale 2001) and underestimates the role of personal networks in the migration process (Staring 2004, Herman, 2006).

Studies that take a wider perspectives show that it is often local people living in border regions involved in the smuggling business for whom profiting from smuggling goods and/or people is a low-profile way of making a living without necessarily being connected to international organized criminal organisations (Chin 1999, Icduygu and Toktas 2000, Mabrouk 2003, Spener 2009, Missbach 2015, Sanchez 2015). These studies also show the complexity around the fact that smuggling is sometimes organized by family members of migrants, who may profit from and exploit relatives, but who are also inclined to act out of humanitarian reasons (Koser 1997, Staring 2004, Buchen, 2014).

\section{Smuggling through social networks}

The role of personal networks has been underestimated in the human smuggling process (Herman 2006) and research on the transnational scope of familial networks has added an important theoretical dimension to the study of human smuggling (Staring 2004). One of the main findings of studies that look into the role of networks is that smuggling depends on unique network characteristics coupled with individual agency, and that trust plays a key role (Koser 2008). Herman (2006) argues for incorporating 'the social non-profit factor' into the study of human smuggling to bring the role of personal and familial ties into the foreground (Herman 2006: 217).

Stefan Buchen (2014) followed a case in Essen (Germany) where in January 2013 'an international people-smuggling gang' was identified as part of a Europe-wide operation. It was reported that suspects were arrested in 37 places across Germany and some arrests were made in Greece and Poland. The 'head of the gang' was a 58-year-old Syrian man from Essen. The authorities estimated that he had made a $€ 300,000$ profit out of smuggling activities, although they did not find any cash. Buchen discovered the 'head of the gang' was not a professional smuggler but an engineer who went to work every day and had not smuggled anything or anyone before the war broke out in Syria. He turned out to be part of a group of Syrians who came together at the beginning of the war to help Syrian refugees escape their country. None of 
their 'customers' had felt threatened, poorly treated, or exploited, and relatively small amounts of money had been paid for the services. This example stands for many smuggling cases and shows that the smuggling market is complex, with highly differentiated services (Icduygu and Toktas 2000, Zhang and Chin 2002, Sanchez 2015). Some earn substantial amounts of money, but many individuals in the smuggling process receive little or no compensation for their services (Kyle and Dale, 2001, 50).

\section{Smuggled migrants' perspectives}

Only few studies have centered around smuggled migrants' perspectives (Koser 1997, EfionayiMader et al. 2001, Bilger et al. 2006, van Liempt 2007, Spener 2009). These studies add an interesting dimension to the debate by pointing out that there is often remarkably little stigma attached to the smuggling business from migrants' points of view. Migrants who have used the services of smugglers rarely view them as dangerous criminals who should be imprisoned, but often describe them as 'the people who most helped them' (Sharma 2003, 60), as life savers, or as a necessary evil in a world with many restrictions on mobility (van Liempt 2007). The fact that there are few migrants willing to testify against their smugglers supports this view of smugglers as helpers. Nevertheless, the prices charged can be very high, and some suffer from exploitation or poor treatment. The important context of helping people escape war, poverty, and misery makes smugglers necessary.

In a quantitative survey carried out with migrants who had enlisted the services of smugglers to cross from Mexico into the USA, 75\% of the 655 interviewees declared that they were satisfied with the service provided by their smuggler, and $45 \%$ would recommend their smuggler to a family member or a friend (Slack and Martínez 2018, p. 162). An additional important reason not to testify against smugglers is that friends/family members who are still back home might one day need these services too. Labeling human smugglers as evil is too simple and does not take into account the political reality that people need to cross borders to find protection.

\section{Smuggling for humanitarian reasons under current EU Law}

Activities of those who provided support to migrants for humanitarian reasons or on the basis of close family ties were previously excluded from the scope of criminalization. The EU Facilitation Directive also has an optional safeguard known as the humanitarian clause which provides EU Member States with the possibility to exempt cases of smuggling from criminalization. Both the UN Protocol and the EU Facilitation Directive risk suppressing genuinely humanitarian acts of assistance, as they give states discretion to criminalize a broad range of acts of assistance to irregular migrants. Carrera and Guild (2016) argue that the Facilitative Directive suffers from an implementation gap in several areas, including the threshold of what constitutes an act of smuggling and the possibility of a humanitarian defense.

The decision to include an optional 'humanitarian clause' was not without discussion and internal disagreements within the EU. Its wording is ultimately the product of a compromise amongst the drafters put forth by the Swedish presidency (Council of the European Union 2001). For example, Austria was entirely opposed to Article 1.2 (the optional humanitarian clause) and the UK submitted several reservations (Council of the European Union 2001). By contrast, Germany proposed that the humanitarian clause should be 'compulsory' (Council of the European Union 2001). Whilst the product of compromise, the optional humanitarian exemption ultimately permits the criminalization of humanitarian acts of smuggling because the 
Directive does not oblige EU member states to impose sanctions when humanitarian motives are involved in smuggling.

As such, countries have varied in how they have transposed this Directive into national legal frameworks. According to Art. 1 (2),

Any member state may decide not to impose sanctions with regard to the behavior defined in paragraph 1 (a) by applying its national law and practice for cases where the aim of the behavior is to provide humanitarian assistance to the person concerned.

Behind this provision lies a clue to the fact that humanitarian concerns are not a key worry for EU laws against smuggling. The meaning of Art. 1 (2) is, indeed, that member states are not obliged, but merely permitted to grant 'facilitators' a humanitarian defense for their conduct, which unavoidably makes helping immigrants more risky for potential helpers, thereby indirectly impinging upon the chances migrants have to be helped when they find themselves in need of humanitarian assistance. Currently, facilitating irregular entry is punished in all $28 \mathrm{EU}$ member states and the EU Actions to fight against smuggling have run in parallel with an incremental use of sanctions in the EU against individuals directly or indirectly involved in helping and/or providing humanitarian assistance to irregular migrants.

A recent report by the EU Fundamental Rights Agency (Fundamental Rights Agency FRA 2014) reveals that only a quarter of member states "have national legislation that reflects, at least in some form, the safeguards in Article 1 (2), allowing states not to impose sanctions when irregular entry is facilitated for humanitarian purposes." The optional humanitarian clause had been explicitly transposed at the national level in only eight Member States. The same FRA report similarly notes that "more than a quarter of member states fail in their national legislation to exempt non-profit acts or humanitarian assistance from the rules of facilitation of stay" (Fundamental Rights Agency FRA 2014). In the autumn of 2015, during which substantial numbers of refugees in desperate situations travelled through both EU and Schengen states, some of the EU's measures against facilitation of irregular migration were instrumentalised by some political leaders to warn their citizens and the citizens of neighbouring states against assisting refugees on the move. EU law, of course, does not disregard completely the rights of smuggled migrants; it could not do so, since many of these rights are either recognised in the EU Charter of the Fundamental Rights or are the object of international obligations for the member states. Two examples. According to Art. 1(2),

Any member state may decide not to impose sanctions with regard to the behaviour defined in paragraph 1(a) by applying its national law and practice for cases where the aim of the behaviour is to provide humanitarian assistance to the person concerned.

The meaning of Art. 1(2) is that member states are not obliged, but merely permitted to grant "facilitators" a humanitarian defence for their conduct, which unavoidably makes helping immigrants more risky for potential helpers, thereby indirectly impinging upon the chances migrants have to be helped when they find themselves in need of humanitarian assistance.

\section{Examples of humanitarian smuggling}

Apart from refugees involved in smuggling countrymen who are in need of help to escape war tarn countries, civil society in Europe has also increasingly become involved in helping refugees with their often difficult border crossing processes. One famous recent example is that of Salam 
Aldeen who helped save lives in the Agean Sea, but was later accused of human smuggling. Aldeen, a 34-year-old man from Denmark, was never trained as a lifeguard but when he saw an overcrowded dinghy sinking off the coast of the Greek island of Lesbos in the summer of 2016 he started to rescue the people. The boat came from Turkey and was haphazardly constructed. It had lasted most of the short (10 kilometer) journey across the Agean Sea but the motor began to dislodge only a few hundred meters off the coast of Lesbos. As the boat started to sank Salam told the people to get off, hold onto the boat and paddle to shore. He helped them push and steer the boat from the back. There were women and children on board and a picture of Salam holding a baby made it all over the news. Back in Denmark, Salam Aldeen decided to go back to Lesbos and see if he could help. He started Team Humanity in September 2015 and he became an 'island legend.' As an almost native Arabic speaker (his father is originally from Iraq) he rescued many migrants. Aldeen had responded to distress calls from more than 200 boats with an estimated total of more than 10,000 refugees on board, seeking to uphold the duty to rescue at sea.

In January 2016 Aldeen was arrested on charges of human smuggling. As the driver and owner of the boat, Aldeen faced harsher punishment than the other rescuers. Four rescuers were given a bail set at 5000 Euros, while Aldeen's bail was set at 10,000 Euros. He faced up to ten years in prison. Also, Aldeen was barred from leaving the country, whereas the others were not. He has to check into a police station every week and is not allowed to leave Greece, just like so many immigrants today who are stuck in Greece. He continued his charity work helping refugees stuck on the Greek islands despite the charges. In May 2018 he faced the Geek court with four co-volunteers and was cleared of charges of bringing migrants into Greece illegally.

Large organizations like Save the Children and Médecins Sans Frontiers (MSF) recently also have been accused of collaborating with human smugglers with their rescue operations in the Central as well as Eastern Mediterranean sea. It is important to contextualize these accusations. The Mare Nostrum Operation, which was initiated after the large shipwreck in 2014 off the coast of Lampedusa, was framed in the discourse of humanitarianism. In late 2014, because of a lack of support from the European Union the Italian state retreated from their Mare Nostrum Operation, leaving thousands to die at sea; it was criticized for a nine-fold increase in deaths between 2014 and 2015. ${ }^{1}$ NGOs such as MSF then stepped in to fill this gap as a response to this danger to life (Pallister-Wilkins 2018). MSF launched its own SAR operations in 2015, initially by providing medical assistance on-board the MOAS' (Migrant Offshore Aid Station) boat. Soon MSF was running boats of its own: the Bourbon Argos; the Dignity 1; and lately the Prudence, while also joining forces with SOS Mediterranean on their the Aquarius (PallisterWilkins 2018). MSF's objective is to save human lives in full respect of its independent mandate as a medical humanitarian organization. SAR efforts produce a mobile humanitarianism that cannot be fixed easily in time or space. It occurs where rescue is needed. The types of care that can be offered and the conditions under which the care is offered depend hugely on politics.

Some politicians and officials in EU member states (for example Italy, Belgium and Austria) now claim that by providing SAR service Mare Nostrum and NGOs have made the journey safer and easier, thereby encouraging migrants and refugees to make the journey, acting thus as a pull factor for migration, or a bridge to Europe, and increasing the numbers. These are claims that are not substantiated with data. A recent assessment compared the before, during and after the Mare Nostrum period showed that the number of arrivals (and deaths) was higher before Mare Nostrum was introduced and during the period that involved NGOs. ${ }^{2}$ By only focusing on who provides the border crossing, the important discussion of why people need to cross borders is left aside, and the complexities involved in migration are overlooked. Human smuggling is increasingly framed as a threat to the state rather than a reaction to restrictions imposed by states (see also Kyle and 
Dale 2001, Kyle and Siracusa 2005). This narrow focus results in a narrow understanding of what human smuggling is, and has an impact on how it is 'combatted.'

\section{Conclusion}

On the European Agenda on Migration the "fight against smugglers and traffickers" has been identified as a key priority. In particular, the Agenda has called for improvements to the current EU legal framework "to tackle migrant smuggling and those who profit from it." However, in the EU Action Plan against Migrant Smuggling adopted in May 2015, the European Commission notes that appropriate criminal sanctions should be in place while avoiding the risks of criminalising those who provide humanitarian assistance to migrants in distress, thus implicitly acknowledging the inherent tension between the criminalisation of smugglers on the one hand and of those providing humanitarian assistance on the other, through a range of behaviours that cover facilitation of not only irregular entry and transit, but also irregular residence and stay.

At present, the overall numbers of investigations and prosecutions leading to effective convictions of migrant smugglers across the entire European Union is low. Several studies have been conducted regarding EU member states' national transposition and implementation of the Facilitators' Package, or more generally, on policies and programmes focused on smuggling across the EU and in cooperation with third countries and the characteristics of the phenomenon. A significant gap exists, however, concerning the actual effects that these laws have on those working at the front line of providing humanitarian assistance, public services and fundamental human rights to irregular migrants, in particular, civil society organisations. What we witness at the borders is that the criminalization of smuggling has affected the willingness of small professional shipmasters to come to the rescue of migrants in distress. Moreover, court cases of convicted individuals have a wider impact on future possible helpers. Suppressing assistance of refugees very well may be the primary aim of criminalization; it is not so much about prosecuting people but much more about warning others not to do this. Criminalization of humanitarian forms of smuggling may thus impact people's willingness to help refugees because it makes helping migrants riskier and indirectly impinges on the chances migrants have to be helped when they find themselves in need of humanitarian assistance.

For the past decade, service providers across several member states have raised concerns that the hardening stance on migrant smuggling at the political level could impact the day-to-day service provision of humanitarian actors. It has been feared that renewed efforts to combat the smuggling of migrants and refugees could affect irregular migrants' access to their fundamental rights, including healthcare, education and housing. As such, it undermines the support for more humane solutions to the refugee crisis.

Protecting the fundamental rights of irregular migrants requires differentiating between smugglers and those providing humanitarian assistance to irregular migrants. This is particularly true as civil societies - NGOs as well as individuals - are often the ones that cover the basic needs of migrants. It is paramount to ensure that those helping migrants are given the legal certainty that they will not be prosecuted for their assistance. It must be acknowledged that family members and friends helping people escape war situations should not be criminalized. More debate is required regarding the significant differences between a citizen's or an NGO's perspective of facilitating irregular entry and transit, and the perspective of the state.

The plight of refugees in dreadful situations has inspired many people in the past and today to reach out and help. Many of these actions could be treated as crimes, under current national rules of the EU against irregular migration. The criminalization of humanitarian acts is evolving 
without much discussion. Getting a humanitarian exemption clause put in the Facilitation Directive could be a way to solve this dilemma. The clause is currently optional and not used by most EU states. The number of states using it is, in fact, decreasing. A humanitarian exemption has proven not to be sufficient. Humanitarian acts in this context must be more narrowly defined, either by making more explicit the meaning of "humanitarian," or defining more clearly the criminal element. A more explicit definition of what constitutes humanitarian here is needed in order not to put 'helpers' at risk.

Narrowing the smuggling definition to acts of facilitation where the smuggler is doing harm, or risk of harm to the individual could also be an option, as Landry (2016) suggests. In the absence of legal pathways, let us not forget that smuggling is usually essential to the ability of most refugees to claim their right under the Refugee Convention, and that criminalization of smuggling will do more harm to refugees than good. Smuggling is often the only means to enjoy fundamental rights, such as living in unity with one's family or escaping violence. The 'fight' against smuggling will only be successful when it is part of a broader set of measures including more promising attempts for conflict resolution and development in regions of origin. It is difficult to challenge the dominant representation of smuggling at a time when many people die as a result of dangerous border crossings, but it is necessary to stress that criminalization of smuggling will not improve migrant's access to protection at a time when mobility is restricted by governments.

\section{Notes}

1 (https://deathbyrescue.org/).

2 (www.law.ox.ac.uk/research-subject-groups/centre-criminology/centreborder-criminologies/blog/2 017/03/border-deaths).

\section{References}

Baird, T. and Liempt, I van (2015) 'Scrutinising the double disadvantage: knowledge production in the messy field of migrant smuggling,' Journal of Ethnic and Migration Studies, 42(3), pp. 400-417.

Bilger, V., Hofmann, M. and Jandl, M. (2006) 'Human smuggling as a transnational service industry. Evidence from Austria,' International Migration, 44(4), pp. 59-93.

Buchen, S. (2014) Die Neuen Staatsfeinde. Wie die Helfer Syrischer Kriegsfluchtlinge in Deutschland kriminalisiert werden. Bonn: Dietz-Verlag.

Carrera, S. and Guild, E. (2016) Irregular Migration, Trafficking and Smuggling of Human Beings: Policy Dilemmas in the EU. Brussels: Centre for European Policy Studies (CEPS).

Chin, K. L., (1999) Smuggled Chinese: Clandestine Immigration to the United States. Philadelphia: Temple University.

Colucello, S. and Massey, S. (2007) 'Out of Africa: the human trade between Libya and Lampedusa,' Trends in Organized Crime, 10, pp. 77-90.

Collyer, M., (2016) Cross-border cottage industries and fragmented migration, in Carrera, S. \& E. Guild (eds.), Irregular Migration, Trafficking and Smuggling of Human Beings: Policy Dilemmas in the EU. Brussels: Centre for European Policy Studies.

Council of the European Union, 6766/01, Brussels, 9 March 2001 (http://data.consilium.europa.eu/doc/ document/ST-6766-2001-INIT/en/pdf).

Efionayi-Mader, D., M. Chimienti, J. Dahinden and Piguet, E. (2001) Asyldestination Europa. Eine Geographie der Asylbewegungen. Zurich: Seismo.

Fittko, L. (2000) Escapes Through the Pyrenees. Illinois: Northwestern University Press.

Fundamental Rights Agency (FRA) (2014) "Criminalisation of migrants in an irregular situation and of persons engaging with them." http://fra.europa.eu/en/publication/2014/criminalisation-migrantsirregular-situationand-persons-engaging-them 


\section{Humanitarian smuggling}

Gallagher, A. T. and David, F. (2014) The International Law of Migrant Smuggling. Cambridge: Cambridge University Press.

Heckmann, F. (2004) 'Illegal migration: what can we know and what can we explain? The case of Germany,' International Migration Review, 38(3), pp. 1103-1125.

Herman, E. (2006) 'Migration as a family business: the role of personal networks in the mobility phase of migration,' International Migration, 44(4), pp. 191-230.

Icduygu, A. and Toktas, S. (2000) 'How do smuggling and trafficking operate via irregular border crossings in the Middle East? Evidence from fieldwork in Turkey,' International Migration, 40(6), pp. 25-52.

Kaizen, J. and Nonneman, W. (2007) 'Irregular migration in Belgium and organized crime: an overview,' International Migration, 45(2), pp. 121-146.

Koser, K., (1997) 'Social networks and the asylum cycle: the case of Iranians in the Netherlands,' International Migration Review, 31(3), pp. 591-611.

Koser, K. (2008) 'Why migrant smuggling pays,' International Migration, 46(2): pp. 3-26.

Kyle, D. and Dale, J. (2001) Smuggling the state back in: agents of human smuggling reconsidered, in Kyle, D. and R. Koslowski (eds.) Global Human Smuggling: Comparative Perspectives. Baltimore: Indiana University Press, pp. 29-57.

Kyle, D. and Siracusa, C. A. (2005) Seeing the state like a migrant: why so many non-criminals break immigration laws, in van Schendel, W. and I. Abraham (eds.) Illicit Flows and Criminal Things. Bloomington: Indiana University Press, pp. 153-176.

Kyle, D. and Koslowski, R., (eds.) (2011) Global Human Smuggling: Comparative Perspectives (2nd edition). Baltimore: The Johns Hopkins University Press.

Landry, R., (2016) The 'Humanitarian Smuggling' of Refugees. Criminal Offence or Moral Obligation?, Oxford: Refugee Studies Centre, Working Paper Series No. 119.

Lazcko, F. and Thompson, D., (eds.) (2000) Migrant Trafficking and Human Smuggling in Europe: A Review of the Evidence with Case Studies from Hungary Poland and Ukraine. Geneva: International Organization for Migration (IOM).

Liempt, I. van (2007) Navigating Borders: Inside Perspectives on the Process of Human Smuggling into the Netherlands. Amsterdam: Amsterdam University Press.

Liempt, I. van and Sersli, S. (2012) 'State responses and migrant experiences with human smuggling: a reality check,' Antipode, 45(5), pp. 1029-1046.

Mabrouk, M. (2003) 'A sociological study of clandestine emigrants and their imaginary,' Revue Semestrielle Tunisiennes de Sciences Social. Tunis: CERES.

Mar, L. (2010) Brokering Belonging: Chinese in Canada's Exclusion Era, 1885-1945. New York: Oxford University Press.

Missbach, A. (2015) Troubled Transit: Asylum Seekers Stuck in Indonesia. Singapore: ISEAS.

Moises N. (2005) Illicit: How Smugglers, Traffickers, and Copycats are Hijacking the Global Economy. New York: Doubleday.

Neske, M. (2006) Menschensmuggel. Deutschland als transit and zielland irregular migration, PhD thesis, University of Bamberg.

Pallister-Wilkins, P. (2018) 'Médecins Avec Frontières and the making of a humanitarian borderscape,' Environment and Planning D: Society \& Space, 36(1), pp. 114-138.

Salt, J. (2000) 'Trafficking and human smuggling: a European perspective,' International Migration, 38(3), pp. 31-56.

Salt, J. and Stein, J. (1997) 'Migration as a business: the case of trafficking,' International Migration, 35(4), pp. 467-494.

Sanchez, G. (2015) Human Smuggling and Border Crossings. Routledge.

Sharma, N. (2003). 'Travel agency: A critique of anti-trafficking campaigns,' Refuge: Canada's Journal on Refugees, pp. 53-65.

Siener, W. (2008) 'Through the back door: Evading the Chinese Exclusion Act along the Niagara Frontier, 1900 to 1924,' Journal of American Ethnic History, 27(4), pp. 34-70.

Slack, J., and Martínez, E. D. (2018) 'What makes a good human smuggler? The difference between satisfaction with and recommendation of coyotes on the U.S.-Mexico border,' The Annals of the American Academy of Political and Social Sciences, 676(1), pp. 152-173.

Soudijn, M. R. J. and Kleemans, E. R. (2009) 'Chinese organized crime and situational context: comparing human smuggling and synthetic drugs trafficking,' Crime Law and Social Change, 52(5), pp. 457-474. 
Spener, D. (2009) Clandestine Crossings: Migrants and Coyotes on the Texas-Mexico Border. New York: Cornell University Press.

Staring, R. (2004) 'Facilitating the arrival of illegal immigrants in the Netherlands: irregular chain migration versus smuggling chains,' Journal of International Migration and Integration, 5(3), pp. 273-294.

UNODC (2011) The Role of Organized Crime in the Smuggling of Migrants from West Africa to the European Union. Vienna: United Nations.

Zhang, S. and Chin, K. L. (2002) The Social Organisation of Chinese Human Smuggling: A Cross National Study. San Diego: San Diego State University. 